\title{
In vitro evaluation of the antimicrobial activity of endodontic sealers
}

\section{Avaliação in vitro da atividade antimicrobiana de cimentos endodônticos}

\author{
Daniela Cristina Miyagak* \\ Elaine Manso Oliveira Franco de Carvalho** \\ Carlos Roberto Colombo Robazza** \\ Jorge Kleber Chavasco** \\ Gustavo Labegalline Levorato*
}

\begin{abstract}
The purpose of this study is to evaluate the antimicrobial activity of the endodontic sealers: N-Rickert, Sealapex, AH Plus, Mineral Trioxide Aggregate (MTA) and portland cement. The Agar diffusion method was used in plates previously inoculated with the following microorganisms: C. albicans, S. aureus, E. faecalis, E. coli. The diameters of microbial inhibition zones were measured after 24 hours of incubation in kiln at $37^{\circ} \mathrm{C}$. According to the methodology used, it was possible to conclude that only the sealers AH Plus and N-Rickert presented antimicrobial activity against $C$. albicans, S. aureus, and E. coli; no antimicrobial activity in MTA, Sealapex and portland cement was observed. N-Rickert presented the largest inhibition zones varying from 8 to $18 \mathrm{~mm}$, and the microorganism E. faecalis was resistant against all sealers tested.
\end{abstract}

DESCRIPTORS: Root canal obturation; Bacteria; Dental cements.

\begin{abstract}
RESUMO: O objetivo deste estudo é avaliar a capacidade antimicrobiana dos cimentos obturadores de canal: N-Rickert, Sealapex, AH Plus e também do Agregado Trióxido Mineral (MTA) e Cimento de Portland. O método utilizado foi a difusão em Ágar, em placas previamente inoculadas com os seguintes microorganismos: C. albicans, S. aureus, E. faecalis, E. coli. A leitura do diâmetro do halo de inibição do crescimento microbiano foi realizada, após 24 horas de incubação, em estufa a $37^{\circ} \mathrm{C}$. De acordo com a metodologia empregada, foi possivel concluir que: somente os cimentos obturadores AH Plus e N-Rickert apresentaram atividade antimicrobiana contra C. albicans, S. aureus e E. coli; não foi observada atividade antimicrobiana no cimento de Portland, MTA e Sealapex. O cimento N-Rickert apresentou halos de inibição maiores variando de 8 a $18 \mathrm{~mm}$. O microorganismo E. faecalis foi resistente contra todos os cimentos testados.
\end{abstract}

DESCRITORES: Obturação do canal radicular; Bactérias; Cimentos dentários.

\section{INTRODUCTION}

The main purpose of endodontic therapy is to clean and shape the root canal by means of instruments and chemical irrigation substances, in order to eliminate or reduce the amount of microorganisms, when the pulp is necrosed. . $^{8,10,14}$

However, infection may persist in canals with high anatomic complexity, with a great number of bacteria, especially facultatively anaerobic bacteria. ${ }^{15}$

In chronic pulpar necrosis, apical cement erosion may occur as well as the presence of bacteria in periradicular tissues, which are resistant against the organic defense of the host and the chemical solutions used in the root therapy. ${ }^{1}$

Most endodontic infections are mixed and polimicrobial, with predominance of strict anaerobes, some facultative anaerobes and rarely aerobes. ${ }^{9}$ In addition, recent studies have associated the presence of fungi with therapy-resistant endodontic infections. . $^{7,16,20}$

After disinfection, the canal is sealed with a root filling, and one of its main properties is to have antimicrobial activity, with potential to eliminate residual microorganisms unaffected by the effects of both chemo-mechanical preparation and intracanal medication. ${ }^{12}$ Besides, the root filling should also help prevent a recurrent root canal infection and aid the repair process of apical and periapical tissues. ${ }^{19}$

Studies reported that only an initial $\mathrm{mi}$ crobial inhibition exists, probably because the

\footnotetext{
* Graduate Students, School of Dentistry; **Adjunct Professors, Department of Clinic and Surgery - Federal University of Alfenas.
} 
Miyagak DC, Carvalho EMOF, Robazza CRC, Chavasco JK, Levorato GL. In vitro evaluation of the antimicrobial activity of endodontic sealers. Braz Oral Res 2006;20(4):303-6.

highest reactivity of the cement happens during the cure. ${ }^{5,13}$

Therefore, the aim of this study was to evaluate the antimicrobial activity of the following endodontic sealers: AH Plus, Portland cement, N-Rickert, Pro Root MTA and Sealapex; in the presence of microorganisms commonly isolated from infected root canals, such as Candida albicans, Enterococcus faecalis, Escherichia coli and Staphylococcus aureus.

\section{MATERIAL AND METHODS}

The materials studied were: AH Plus (Dentsply DeTrey GmbH, Germany, 2003), Portland cement (Barroso, São Paulo, Brazil, 2003), N-Rickert (Fórmula e Ação - Manipulação, São Paulo, Brazil, 2003), Pro Root MTA (Dentsply DeTrey GmbH, Germany, 2003) and Sealapex (Kerr Corp, USA, 2003). The microorganisms used in this study were: 1 . Candida albicans (ICB/USP 562), 2. Enterococcus faecalis (ATCC 29212), 3. Escherichia coli (ATCC 25922), 4. Staphylococcus aureus (ATCC 6538). All microorganisms used in this study came from the laboratory of Immunology, Federal University of Alfenas, MG, Brazil.

Four (4) petri dishes previously sterilized were prepared containing BHI agar (Merck, São Paulo, Brazil, 2003), in the necessary volume to obtain five (5) $\mathrm{mm}$ of thickness. On each dish, five (5) perforations were made with a metal tube with four (4) $\mathrm{mm}$ of diameter to receive the testing materials. Each microorganism was scattered on the dishes with a swab. The sealers under study were handled according to the manufacturer's instructions and placed in the wells immediately after mixing. After the sealers setting, the agar plates were incubated at $37^{\circ} \mathrm{C}$ for 24 hours to allow the microorganisms to grow and reagents to diffuse through the culture medium. After incubation, the inhibition zones formed around the wells containing the sealers were measured. All experiments were made three times, and the results were the average values of the three records.

\section{RESULTS}

The results obtained according to the methodology used are presented in Figures 1 and 2 and Table 1.

The sample distribution was not normal and a non-parametrical test was required.
The results of the statistical analysis revealed significant differences (5\%) when comparing AHPlus with MTA, Portland and Sealapex.

No difference was found when comparing AHPlus with N-Rickert.

When comparing N-Rickert with MTA, Portland and Sealapex, the mean difference was significant $(1 \%)$.

\section{DISCUSSION}

In this study, we used the agar diffusion test, which is the most widely used in vitro method for the evaluation of antimicrobial activity. ${ }^{6}$ This method allows direct comparisons between materials and also indicates which sealers are more likely to have antimicrobial activity within the root canal system. ${ }^{12}$ Besides that, its results are highly influenced by the diffusibility of the material across the medium. ${ }^{4}$

Most endodontic sealers possess antimicrobial components that need to be released from the sealer matrix to be effective. The test sealers showed no permanent residual antibacterial effects. ${ }^{12}$

Our results showed that the most resistant microorganism to the antimicrobial activity of all sealers tested was Enterococcus faecalis. This is one of the most resistant species usually found in root canal infections. ${ }^{10}$ It is usually persistent and difficult to treat. ${ }^{2}$ It is frequently associated with failure of the root canal treatment. ${ }^{16}$

The existence of antimicrobial activity in Portland cement and MTA was not observed, even though their $\mathrm{pH}$ reached 12.5, similar to that of calcium hydroxide, which could lend some antimicrobial properties to them, according to Torabinejad et al. ${ }^{17,18}$ (1995).

The results of the present study agree with those obtained by Estrela et $a .^{3}{ }^{3}$ (2000).

The same result obtained with MTA also applies to Portland cement, with no significant difference. The fact that the main components of MTA are also found in Portland cement can justify why the results of their antimicrobial activity tests were similar. ${ }^{3}$

The N-Rickert sealer presented the best antimicrobial activity among the sealers tested, probably due to its components, such as oil of cloves, aristol and silver.

The AH-Plus sealer presented antimicrobial activity too because of the components of the epoxy resin and due to the discreet liberation of formaldehyde. ${ }^{12}$ 
Miyagak DC, Carvalho EMOF, Robazza CRC, Chavasco JK, Levorato GL. In vitro evaluation of the antimicrobial activity of endodontic sealers. Braz Oral Res 2006;20(4):303-6.
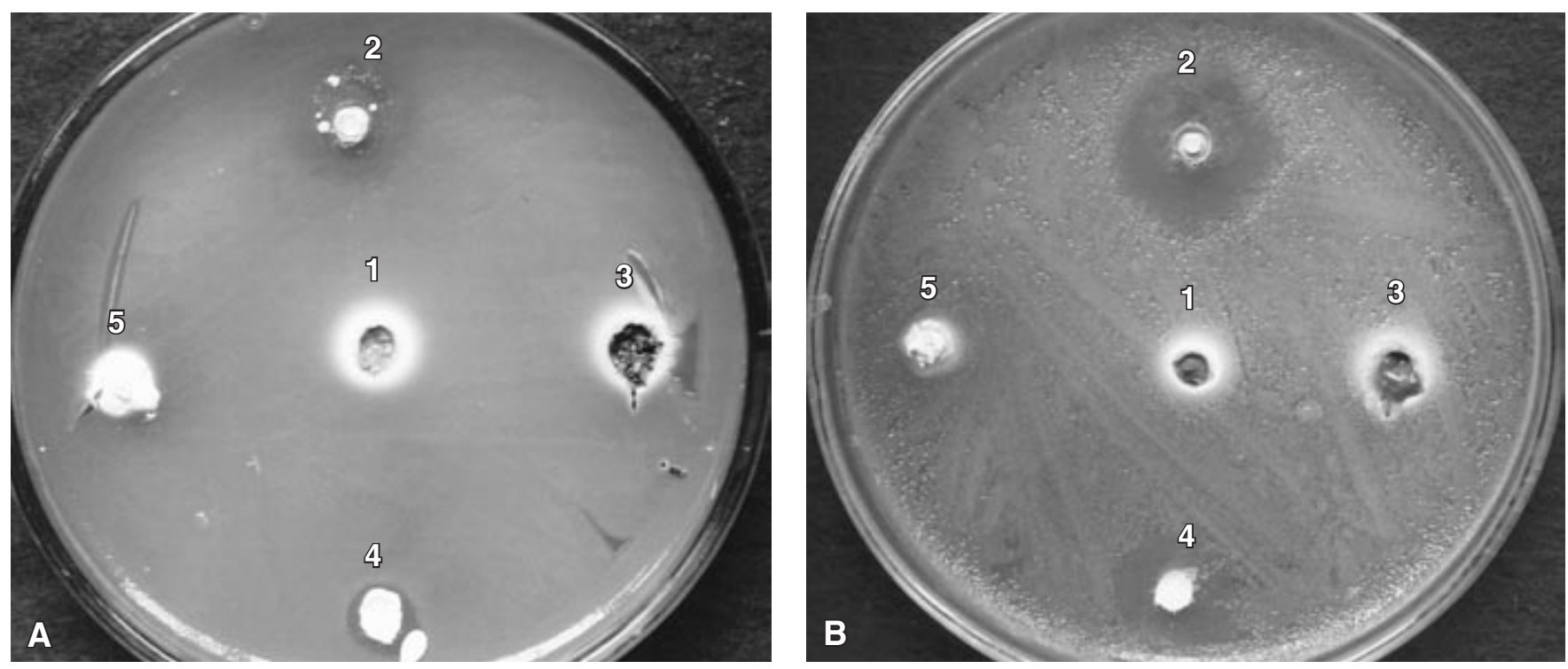

FIGURE 1 - Inhibiton zones promoted by the sealers 1. Portland, 2. N-Rickert, 3. MTA, 4. AH Plus, 5. Sealapex against Escherichia coli (A) and Candida albicans (B).
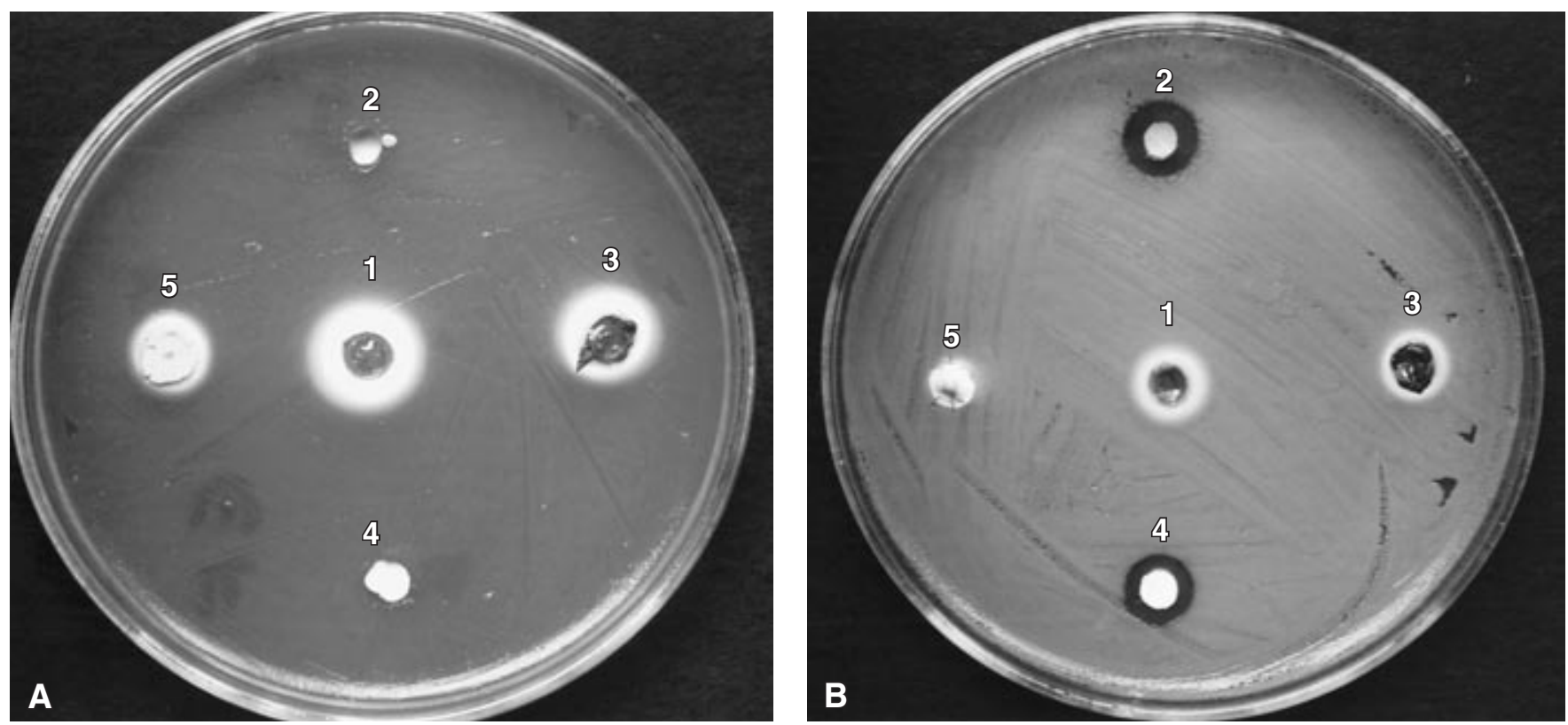

FIGURE 2 - Inhibiton zones promoted by the sealers 1. Portland, 2. N-Rickert, 3. MTA, 4. AH Plus, 5. Sealapex against Enterococcus faecalis (A) and Staphylococcus aureus (B).

\begin{tabular}{|c|c|c|c|c|c|}
\hline \multirow{5}{*}{$\begin{array}{r}\text { TABLE 1 - In vitro } \\
\text { evaluation of the } \\
\text { antimicrobial } \\
\text { activity of } \\
\text { endodontic } \\
\text { sealers. Inhibition } \\
\text { zones in } \\
\text { millimeters. }\end{array}$} & \multirow[b]{2}{*}{ Materials } & \multicolumn{4}{|c|}{ Microorganisms } \\
\hline & & $\begin{array}{l}\text { Candida } \\
\text { albicans }\end{array}$ & Escherichia coli & $\begin{array}{l}\text { Enterococcus } \\
\text { faecalis }\end{array}$ & $\begin{array}{c}\text { Staphylococcus } \\
\text { aureus }\end{array}$ \\
\hline & AH Plus & $10 \mathrm{~mm}$ & $6 \mathrm{~mm}$ & 0 & $7 \mathrm{~mm}$ \\
\hline & MTA & 0 & 0 & 0 & 0 \\
\hline & N-Rickert & $18 \mathrm{~mm}$ & $12 \mathrm{~mm}$ & 0 & $8 \mathrm{~mm}$ \\
\hline & Portland & 0 & 0 & 0 & 0 \\
\hline & Sealapex & 0 & 0 & 0 & 0 \\
\hline
\end{tabular}


Miyagak DC, Carvalho EMOF, Robazza CRC, Chavasco JK, Levorato GL. In vitro evaluation of the antimicrobial activity of endodontic sealers. Braz Oral Res 2006;20(4):303-6.

As for Sealapex, no antimicrobial activity was observed, as it depends on ionization that releases hydroxyl ions, increasing the medium $\mathrm{pH}$. However, it requires an adequate time for its effective action against microorganisms. ${ }^{6}$

Siqueira, de Uzeda ${ }^{11}$ (1997) reported that the culture medium can influence the solubility, liberation of ions and alkalinity of calcium hydroxide, which are essential conditions for the antimicrobial effect.

\section{CONCLUSION}

According to the methodology used, it was possible to conclude that none of the materials tested presented antimicrobial activity against $E$. faecalis. The sealers AH-Plus and N-Rickert presented antimicrobial activity against C. albicans, S. aureus, and $E$. coli. No antimicrobial activity was observed in MTA, Sealapex and Portland cement.

\section{REFERENCES}

1. Barbosa CAM, Gonçalves RB, Siqueira JF Jr, De Uzeda M. Evaluation of the antibacterial activities of calcium hydroxide, chlorhexidine, and camphorated paramonochlorophenol as intracanal medicament. A clinical and laboratorial study. J Endod. 1997;23(5):297-300.

2. Engström B. The significance of enterococci in root canal treatment. Odontol Revy. 1964;15:87-106.

3. Estrela C, Bammann LL, Estrela CR, Silva RS, Pécora JD. Antimicrobial and chemical study of MTA, Portland cement, calcium hydroxide paste, Sealapex and Dycal. Braz Dent J. 2000;11:3-9.

4. Fraga RC, Siqueira JF Jr, de Uzeda M. In vitro evaluation of antibacterial effects of photo-cured glass ionomer liners and dentin bonding agents during setting. J Prosthet Dent. 1996;76:483-6.

5. Georgopoulou M, Kontakiotis E, Nakou M. In vitro evaluation of the effectiveness of calcium hydroxide and paramonochlorophenol on anaerobic bacteria from the root canal. Endod Dent Traumatol. 1993;9:249-53.

6. Leonardo MR, da Silva LAB, Tanomaru Filho M, Bonifácio $\mathrm{KC}$, Ito IY. In vitro evaluation of antimicrobial activity of sealers and pastes used in endodontics. J Endod. 2000;26:391-4.

7. Nair PNR, Sjogren U, Krey G, Kahnberg KE. Intraradicular bacteria and fungi in root-filled, asymptomatic human teeth with therapy-resistant periapical lesions: A long-term light and electron microscopic follow-up study. J Endod. 1990;16:580-8.

8. Patel V, Santerre JP, Friedman S. Suppression of bacterial adherence by experimental root canal sealers. J Endod. 2000;26:20-4.

9. Peciuliene V, Balciuniene I, Eriksen HM, Haapasalo M. Isolation of Enterococcus faecalis in previously root-filled canals in Lithuanian population. J Endod. 2000;26:5935.

10. Siqueira JF Jr, Batista MMD, Fraga RC, de Uzeda M. Antibacterial effects of endodontic irrigants on black-pigmented gram-negative anaerobes and facultative bacteria. J Endod. 1998;24:414-6.
11. Siqueira JF Jr, de Uzeda M. Intracanal medicaments: evaluation of the antibacterial effects of chlorhexidine, metronidazole, and calcium hydroxide associated with three vehicles. J Endod. 1997;23:167-9.

12. Siqueira JF Jr, Favieri A, Gahyva SMM, Moraes SR, Lima KC, Lopes HP. Antimicrobial activity and flow rate of newer and established root canal sealers. J Endod. 2000;26:274-7.

13. Siqueira JF Jr, Gonçalves RB. Antibacterial activities of root canal Sealers against selected anaerobic bacteria. J Endod. 1996;22:79-80.

14. Siqueira JF Jr, Lima KC, Magalhães FAC, Lopes HP, de Uzeda M. Mechanical reduction of the bacterial population in the root canal by three instrumentation techniques. J Endod. 1999;25:332-5.

15. Siren EK, Haapasalo MPP, Ranta K, Salmi P, Kerosuo ENJ. Microbiological findings and clinical procedures in endodontic cases selected for microbiological investigation. Int Endod J. 1997;30:91-5.

16. Sundqvist G, Figdor D, Persson S, Sjogren U. Microbiologic analysis of teeth with failed endodontic treatment and the outcome of conservative re-treatment. Oral Surg Oral Med Oral Pathol Oral Radiol Endod. 1998;85:86-93.

17. Torabinejad M, Hong CU, McDonald F, Pitt Ford TR. Physical and chemical properties of a new root-end filling material. J Endod. 1995;21:349-53.

18. Torabinejad M, Hong CU, Pitt Ford TR, Kettering JD. Antibacterial effects of some root-end filling materials. J Endod. 1995;21:403-6.

19. Tronstad L, Andreasen JO, Hasselgren G, Kristerson L, Riis I. pH changes in dental tissues after root canal filling with calcium hydroxide. J Endod. 1980;7:17-21.

20. Waltimo TMT, Siren EK, Torkko HLK, Olsen I, Haapasalo MPP. Fungi in therapy-resistant apical periodontitis. Int Endod J. 1997;30:96-101.

Received for publication on Mar 28, 2005

Sent for alterations on Oct 07, 2005

Accepted for publication on Mar 22, 2006 
This article has received corrections in agreement with the ERRATUM published in Volume 21 Number 1. 